\title{
THE CORE COMPETENCIES \\ IN HOSPITAL MEDICINE \\ A Framework for Curriculum Development \\ By the Society of Hospital Medicine
}

\section{Editors}

Michael J. Pistoria, DO, FACP

Associate Program Director, Internal Medicine Program

Medical Director, Hospitalist Services

Lehigh Valley Hospital

Allentown, PA

Assistant Professor of Medicine

The Pennsylvania State University College of Medicine Hershey, PA

Alpesh N. Amin, MD, MBA, FACP

Executive Director, Hospitalist Program

Vice Chair for Clinical Affairs and Quality, Department of Medicine Associate Program Director, Internal Medicine Residency

Medicine Clerkship Director

University of California, Irvine Orange, CA

Daniel D. Dressler, MD, MSc

Director, Hospital Medicine Services

Emory University Hospital

Assistant Professor of Medicine

Emory University School of Medicine

Atlanta, GA

Sylvia C. W. McKean, MD

Medical Director

Brigham and Women's Faulkner Hospitalist Service

Assistant Professor of Medicine

Harvard Medical School

Boston, MA

Tina L. Budnitz, MPH

Senior Advisor for New Initiatives

Society of Hospital Medicine

Philadelphia, PA

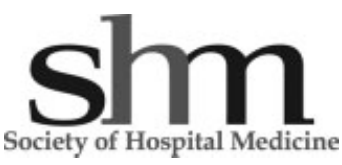


Copyright ( 2006 Society for Hospital Medicine. Published by John Wiley \& Sons. All rights reserved. No part of this publication may be reproduced in any form or by any means, except as permitted under Sections 107 or 108 of the 1976 United States Copyright Act, without either the prior written permission of the publisher, or authorization through the Copyright Clearance Center, 222 Rosewood Drive, Danvers, MA 01923: (978) 750-8400: fax (978) 646-8600. The copyright notice appearing at the bottom of the first page of an article in this journal indicate the copyright owner's consent that copies of the article may be made for personal or internal use, or for the personal use of specific clients, on the condition that the copier pay for copying beyond that permitted by Sections 107 or 108 of the U.S. Copyright Law. This consent does not extend to other kinds of copying, such as copying for general distribution, for advertising or promotional purposes, for creating new collective works, or for resale. Such permission requests and other permission inquiries should be addressed to the Permissions Department, John Wiley \& Sons, Inc., 111 River Street, Hoboken, NJ 07030; (201) 748-6011, fax (201) 748-6008, http://www.wiley.com/go/permissions.

All materials published, including but not limited to original research, clinical notes, editorials, reviews, reports, letters, and book reviews represent the opinions and views of the authors and do not reflect any official policy or medical opinion of the institutions with which the authors are affiliated, SHM, or of the Publisher unless this is clearly specified. Materials published herein are intended to further general scientific research, understanding, and discussion only and are not intended and should not be relied upon as recommending or promoting a specific method, diagnosis, or treatment by physicians for any particular patient. While the Editors, Society, and Publisher believe that drug selections and dosages and the specifications and usage of equipment and devices as set forth herein are in accord with current recommendations and practice at the time of publication, they accept no legal responsibility for any errors or omissions, and make no warranty, express or implied, with respect to material contained herein. Publication of an advertisement or other discussions of products in this publication should not be construed as an endorsement of the products or the manufacturers' claims. Readers are encouraged to contact the manufacturers with any questions about the features or limitations of the products mentioned.
The Journal of Hospital Medicine (Print ISSN 1553-5592; online ISSN 1553-5606 at Wiley InterScience, www.interscience.wiley.com) is published bimonthly, one volume per year, for the Society of Hospital Medicine by Wiley Subscription Services, Inc., a Wiley Company, 111 River Street, Hoboken, NJ 07030. Periodicals postage pending at Hoboken, NJ, and at additional mailing offices. Subscription price Nolume 1 , 2006): Complimentary online access to Journal of Hospital Medicine will be available to all institutions who register for access. Personal rate: $\$ 110.00$. All subscriptions containing a print element shipped outside US will be sent by air. Payment must be made in US dollars drawn on a US bank. Claims for undelivered copies will be accepted only after the following issue has been delivered. Please enclose a copy of the mailing label. Missing copies will be supplied when losses have been sustained in transit and where reserve stock permits. Please allow four weeks for processing a change of address. For subscription inquiries, please call (201) $748-6645$ or e-mail: SUBINF0@wiley.com.

Postmaster: Send address changes to Journal of Hospital Medicine, Subscription Distribution, John Wiley \& Sons, Inc., 111 River Street, Hoboken, NJ 07030.

Advertising Sales: Inquiries concerning advertising should be directed to: (display advertising) Patrice Culligan, National Account Manager, (212) 904-0369, pculligan@pminy.com; (recruitment) Robert Zwick, Classified Advertising Manager, (212) 904-0377, rzwick@pminy.com; Pharmaceutical Media Inc., 30 East 33 rd Street, $4^{\text {th }}$ Floor, New York, NY 10016.

Reprints: Reprint sales and inquiries should be directed to the Customer Service Department, John Wiley \& Sons, Inc., 111 River Street, Hoboken, NJ 07030. Tel: (201) 748-8789.

Other correspondence: Address all other correspondence to: Journal of Hospital Medicine, Publisher, John Wiley \& Sons, Inc., 111 River Street, Hoboken, NJ 07030

Instructions for Authors for preparation of manuscript appear online at http://www.interscience.wiley.com/jhm.

$\infty$ This paper meets the requirements of ANSI/NISO Z39.48-1992 (Permanence of Paper). 


\section{THE CORE COMPETENCIES IN HOSPITAL MEDICINE \\ A Framework for Curriculum Development \\ by the Society of Hospital Medicine}

\section{TABLE OF CONTENTS}

Acknowledgement . $\mathrm{V}$

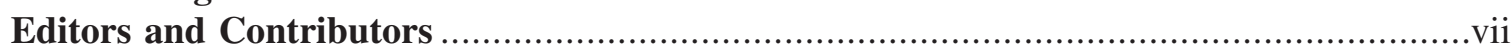

\section{Section 1: $\quad$ CLINICAL CONDITIONS}

$1.1 \quad$ Acute Coronary Syndrome................................................................

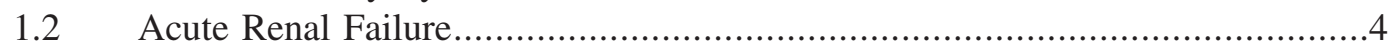

1.3 Alcohol and Drug Withdrawal ...........................................................

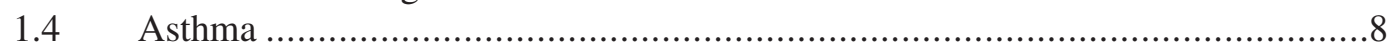

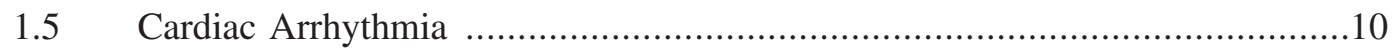

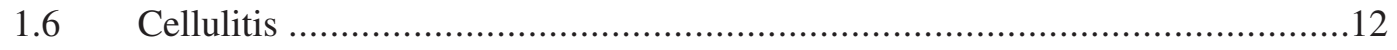

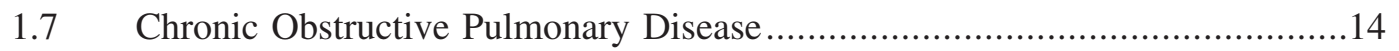

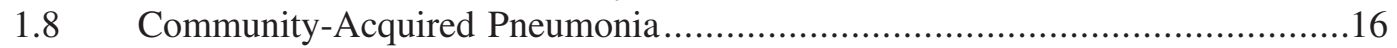

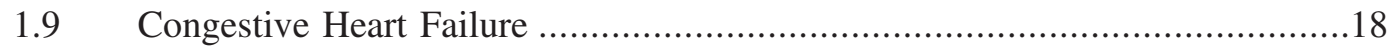

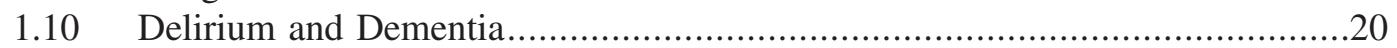

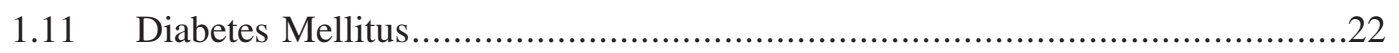

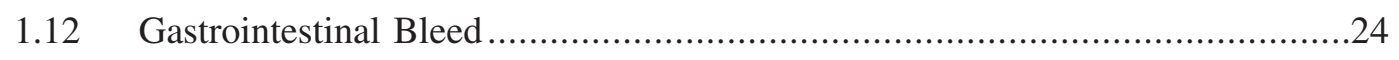

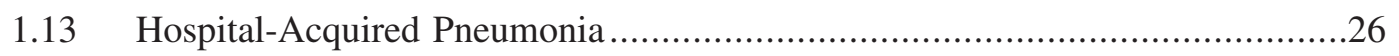

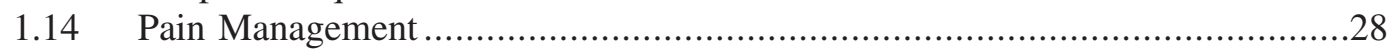

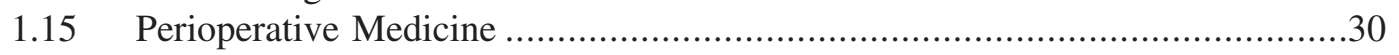

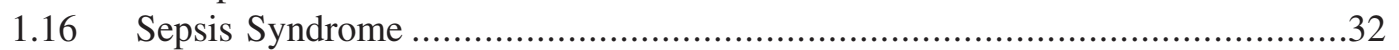

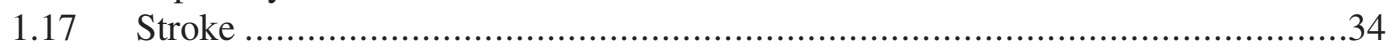

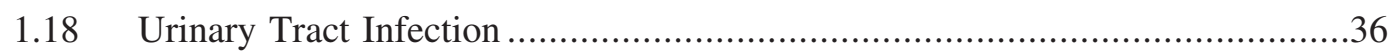

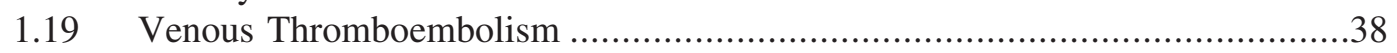

\section{Section 2: $\quad$ PROCEDURES}

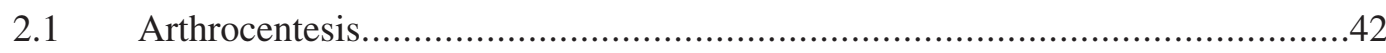

2.2 Chest Radiograph Interpretation ......................................................44

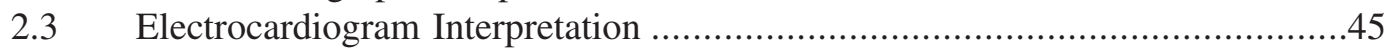

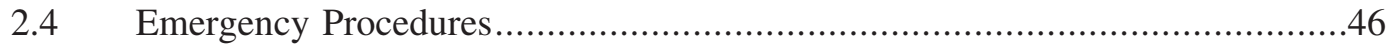

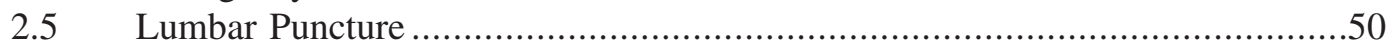

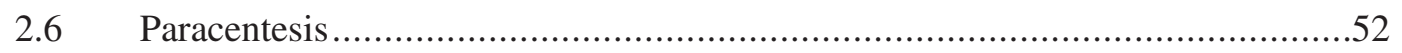

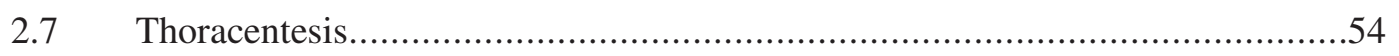

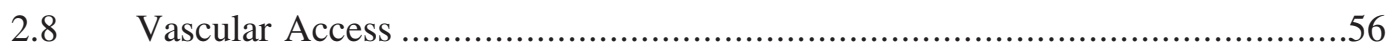




\section{Section 3: $\quad$ HEALTHCARE SYSTEMS}

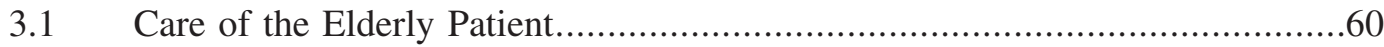

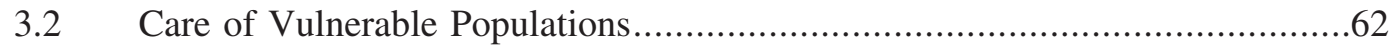

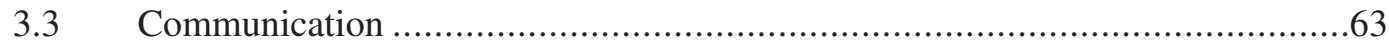

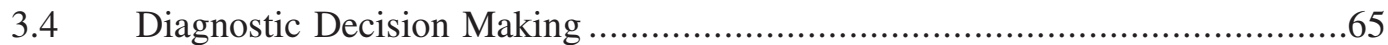

3.5 Drug Safety, Pharmacoeconomics and Pharmacoepidemiology ....................66

3.6 Equitable Allocation of Resources.................................................................68

3.7 Evidence Based Medicine .................................................................69

3.8 Hospitalist as Consultant.................................................................. 70

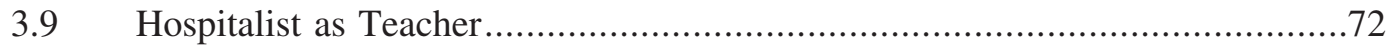

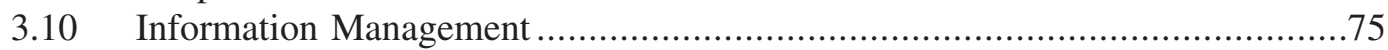

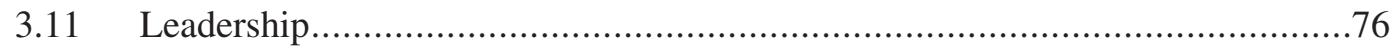

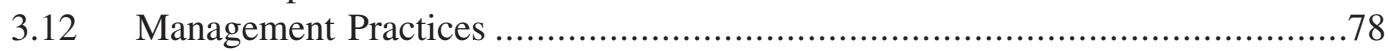

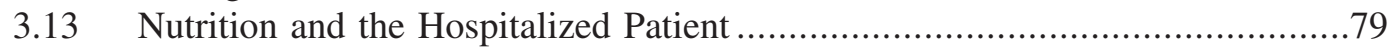

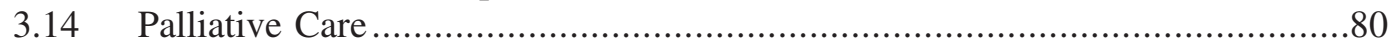

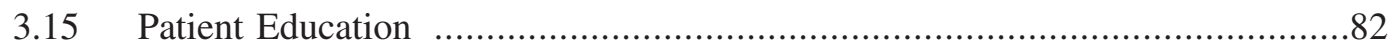

3.16 Patient Handoff ............................................................................. 83

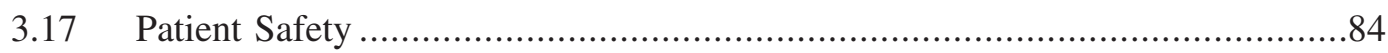

3.18 Practice Based Learning and Improvement ............................................87

3.19 Prevention of Healthcare Associated Infections and Antimicrobial Resistance....88

3.20 Professionalism and Medical Ethics .............................................................90

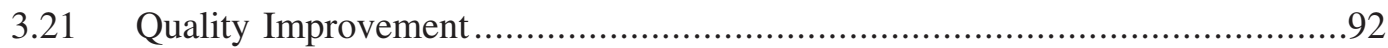

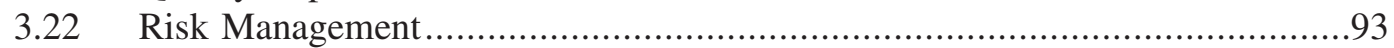

3.23 Team Approach and Multidisciplinary Care...............................................94

3.24 Transitions of Care ........................................................................ 95

\section{APPENDICES}

I. Abbreviations

\section{Organizations Cited in Text}

III. Core Competencies in Hospital Medicine: Development and Methodology Daniel D. Dressler, Michael J. Pistoria, Tina L. Budnitz, Sylvia C. W. McKean, and Alpesh N. Amin Reprinted from Journal of Hospital Medicine, Volume 1, Number 1, 2006, Pages 48-56

IV. How to Use The Core Competencies in Hospital Medicine: A Framework for Curriculum Development Sylvia C. W. McKean, Tina L. Budnitz, Daniel D. Dressler, Alpesh N. Amin, and Michael J. Pistoria Reprinted from Journal of Hospital Medicine, Volume 1, Number 1, 2006, Pages 57-67 